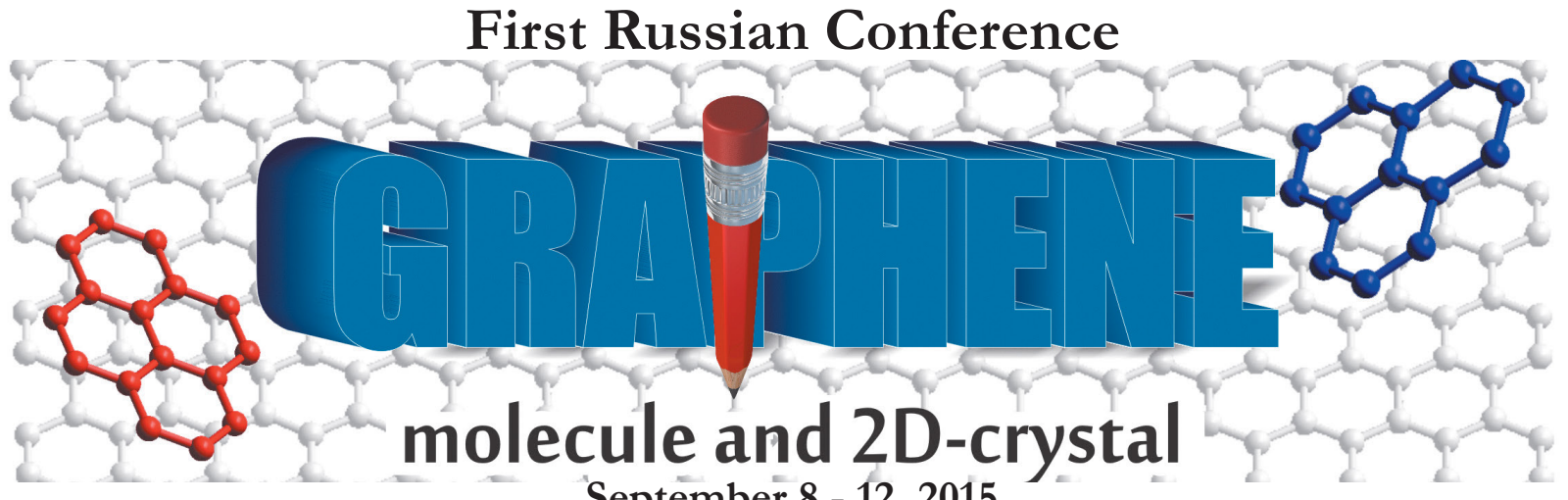

September 8 - 12, 2015

Russian Federation, 630090 Novosibirsk

http://niic.nsc.ru/conferences/graphene

Russian Academy of Sciences

GENERAL CHAIRS:

SERgey P. GubIN

Dr Sci. Chem, prof., IGIC RAS, Moscow

gubin@igic.ras.ru

Alexander V. Окотrub

DrSci. Physe\&Math, prof., NIIC SB RAS, Novosibirske. spectrum@ niic.nsc.ru

\section{PROGRAM COMMITEE}

VALERY I. BUKHTTYAROV

Corr. Memb. RAS, BIC SB RAS, Novosibirsk

VIKTOR A. BYKOV

Dr Sci Techn., prof., NIIFP - NTMDT, Zelenograd

SERGEY P. GUBIN

Dr Sci. Chem, prof., IGIC RAS, Moscom

Alexander V. Eletsky

Dr Sci. Physe 'Math, prof., NRC KI, Mocsow

ZINFER R ISMAGIOOV

ZINFER R. ISMAGILOV
Corr. Memb. RAS, ICCMS SB RAS, Novosibirsk

VLADIMIR L. KUZNETSOV
PhD Chem., BIC SB RAS, Novosibirsk.

ALEXANDER V. LATYSHEV

ALEXANDER V. LATYSHEV
Corr. Memb. RAS, ISP SB RAS, Novosibirsk

Corr. Memb. RAS, ISP SB R

SERGEY A. MaKSIMENKo
Dr Sci. Physe'Math., prof., BSU, Minsk.

Konstantin S. Novoselov

PbD, prof., University of Manchester, United Kingdom

Alexander N. Obraztsoy

Dr Sci. Physe $\&$ Math., prof., MSU, Moscow

ELENA D. OBRazTSOVA
PhD PhyséMath, GPI RAS, Mocsow

VLADIMIR P. FEDIN
Corr. Memb. RAS, NIIC SB RAS, Novosibirsk.

GM2dC'2015/NOVOSIBIRSK

SECRETARIAT

In Novosibirsk:

Yuliya V. FedoseEva

PhD Phys $\dot{*}$ Math, NIIC SB RAS, Novosibirsk

fedoseeva@niic.nsc.ru

graphene@ , niic.nsc.ru
$+73833305352,+79232212008$

IRINA V. ANTONOVA

Dr Sci. Physe'Math, ISP SB RAS, Novosibirsk. antonova@isp.nsc.ru

VIKTOR O. KOROTEEV

VIKTOR O. KOROTEEV
PhD Chem., NIIC SB RAS, Novosibirsk

In Moscow:

Elena Yu. Buslaeva

Dr Sci. Chem. IGIC RAS, Moscom

eyubuslaeva@inbox.ru

Vladimir I. GracheV

IRE RAS, Moscow

grachev@cplire.ru
+79168592707.

\begin{tabular}{|c|c|c|}
\hline \multicolumn{3}{|c|}{$\begin{array}{c}\text { Russian Academy of Sciences } \\
\text { Nikolaev Institute of Inorganic Chemisry SB RAS } \\
\text { Boreskov Institute of Catalysis SB RAS } \\
\text { Rzhanov Institute of Semiconductor Physics SB RAS } \\
\text { Kurnakov Institute of General and Inorganic Chemisry RAS } \\
\text { Novosibirsk State University }\end{array}$} \\
\hline \multicolumn{3}{|c|}{$\begin{array}{l}\text { GM2dC'2015 - brand of the new Russian conference "GRAPHENE - A MOLECULE AND } \\
\text { 2D-CRYSTAL", the first conference in Russia devoted to the results and prospects of } \\
\text { research on graphene and related materials. Conference is purposely interdisciplinary, as } \\
\text { the problem itself. One of the conference objectives is to develop a common language } \\
\text { (terminology) in the discussion of the unique properties of graphene for professionals } \\
\text { from various fields of science, a single view of the prospects in this direction. } \\
\text { Conference language is Russian and English } \\
\text { (with synchronical translation) }\end{array}$} \\
\hline \multicolumn{3}{|c|}{ 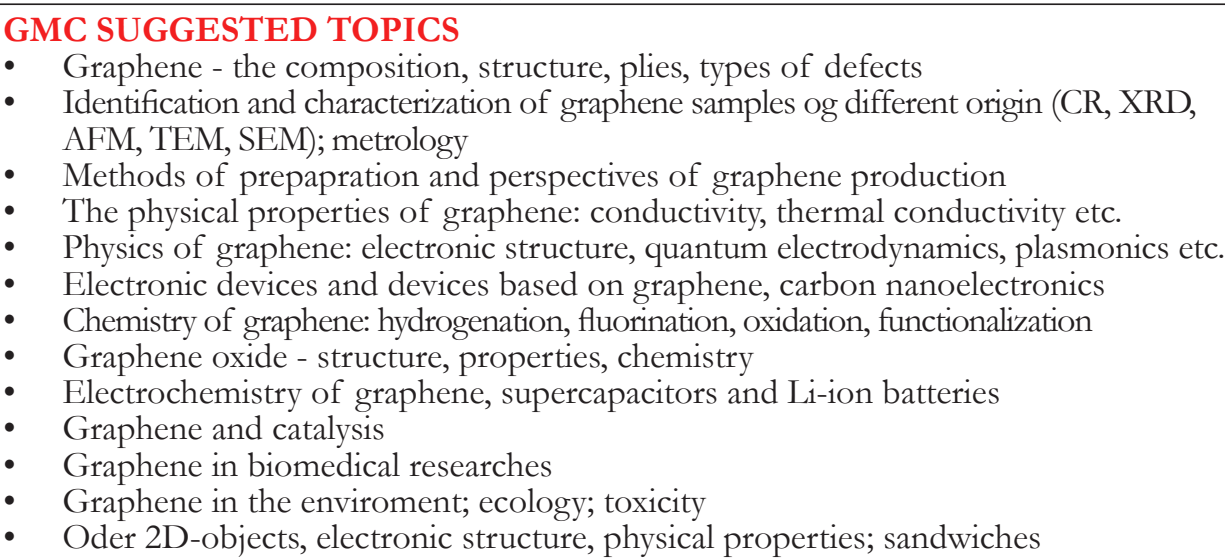 } \\
\hline & $\begin{array}{l}\text { IMPORTANT DATES } \\
\text { Registration and abstract submission deadline } \\
\text { Acceptance notification } \\
\text { Payment of registration fee deadline } \\
\text { Conference program } \\
\text { Full paper submission in journal RENSIT }\end{array}$ & $\begin{array}{ll}\text { May } & 01,2015 \\
\text { May } & 30,2015 \\
\text { Juli } & 15,2015 \\
\text { August } & 20,2015 \\
\text { September } & 08,2015\end{array}$ \\
\hline \multicolumn{3}{|c|}{$\begin{array}{l}\text { VENUE } \\
\text { House of Scientists, Academgorodok, Novosibirsk }\end{array}$} \\
\hline \multicolumn{3}{|c|}{$\begin{array}{l}\text { ACCOMMODATION OF PARTICIPANTS } \\
\text { Hotel "Golden Valley" (with transfer from the airport to the hotel) }\end{array}$} \\
\hline
\end{tabular}

Radioelectronics. Nanosystems. Information Technologies (abbr. RENSIT)

Certificate El. no. FS77-60275 on 19.12.2014 of the Ministry of Telecom and Mass Communications of Russian Federation, Moscow ISSN: 2414-1267online. Http:/ /www.rensit.ru. Publisher - Vladimir I. Grachev. 2015, 30 Juni.

Computer printing, page-proofs, graphics, photos of work - the editors RENSIT 